\title{
KEUNTUNGAN ALGORITMA BEZIER, B-SPLINE DI DUNIA INDUSTRI
}

\author{
Djunaidy Santoso; Haryono Soeparno; Ayuliana \\ Computer Science Department, School of Computer Science, Binus University \\ Jl. K.H. Syahdan No. 9, Palmerah, Jakarta Barat 11480 \\ djunsan2002@yahoo.com
}

\begin{abstract}
Graphic Computers are widely used in various fields, especially in industries, companies, banks and hospitals. At hospital, computer graphics with leading edge techniques support images related to patient's needs. Graphic computer can also be used for shipbuilding and automotive design, as well as decision-makers in an institution, using pictures or images that can be analyzed to produce good forms which the accuracy is still investigated (CAD and CAM). The purpose of research is linking algorithms by creating the right picture or image to a form required by decision makers to associate algorithms Hermite, Bezier, B-Spline in harmonious function of each, so that the curves, images or images are produced better, and can be used in the field of engineering drawings. This research produces an image/ shape/ image which are suitable for designers' need.
\end{abstract}

Keywords: computer graphics, algorithms, blending functions, curve, pictures, image, CAD/ CAM

\begin{abstract}
ABSTRAK
Grafika Komputer banyak digunakan di berbagai bidang, terutama dalam industri, perusahaan, perbankan serta Rumah Sakit. Pada rumah sakit, grafika komputer dengan tekniknya yang sangat mutahir diperuntukkan untuk pemecahan masalah gambar atau citra untuk kebutuhan pasien. Grafika komputer dapat juga digunakan untuk desain perkapalan dan otomotif, maupun pengambil keputusan di suatu Institusi, dengan menggunakan gambar ataupun citra yang dapat di analisis sehingga menghasilkan bentuk yang baik yang sampai sekarang ini terus diteliti ketepatannya (CAD maupun CAM). Tujuan dari penelitian yaitu menghubungkan algoritma dengan menciptakan gambar atau citra yang tepat untuk suatu bentuk yang dibutuhkan oleh para pengambil keputusan dengan mengasosiasikan Algoritma Hermite, Bezier, B-Spline pada fungsi harmonisnya masing-masing, sehingga kurva, gambar maupun citra yang dihasilkan menjadi lebih baik, dan dapat digunakan di dalam bidang rekayasa gambar. Penelitian ini menghasilkan suatu gambar/bentuk/citra yang memadai kebutuhan para perancang gambar ataupun citra.
\end{abstract}

Kata kunci: grafika komputer, algoritma, fungsi blending, kurva, citra, CAD, CAM 


\section{PENDAHULUAN}

Dari data-data statistik industri/perusahaan atau institusi lainnya, banyak kurva/citra yang tidak mulus atau terdapat zig zag, sehingga tidak dapat dipergunakan sebagaimana mestinya. Perlu adanya penanganan khusus untuk menghasilkan citra sesuai dengan kualitas yang diinginkan, seperti menggunakan software untuk mengeluarkan gambar/citra/bentuk dalam pelayanan para pemakai (misalnya AutoCad, microsoft word, Paintbrush 3Dmax, dll).

Menurut Rogers dan Adams (1998), semakin banyaknya algoritma dalam bidang grafik komputer semakin banyak waktu untuk pengambilan keputusan dalam menentukan pendekatan pemakaian rumusan/algoritma yang sesuai. Untuk itu perlu adanya penelitian algoritma/rumusan yang baik dalam menghadapi rancangan bentuk gambar (kurva) yang disesuaikan dengan keinginan pengguna.

Penelitian ini dikembangkan dengan tujuan untuk merancang kurva/gambar/citra bagi industri otomotif (gambar mesin), kapal terbang/laut, desain rumah. Selain itu, untuk menganalisis dengan baik atau merancang/membuat kurva/citra secara mulus dari gambar satelit (GIS) sehingga dapat dipergunakan di bidang statistik dan Rumah Sakit serta industri percetakan dan lain lainnya.

\section{METODE}

Penelitian ini akan dilakukan dengan metodologi sebagai berikut: (1) studi literatur pencarian data dan informasi di internet, hal ini dilakukan untuk mendapatkan informasi terkini mengenai perkembangan metode dan model perancangan pnelitian, dan juga untuk mengetahui dan mempelajari metode yang telah ada dan sedang digunakan; (2) analisis data untuk menganalisis data yang telah terkumpul; (3) perancangan sistem untuk mendapatkan kebutuhan user dan kebutuhan perancangan sistem; (4) implementasi sistem untuk membuat simulasi/model sehingga diperoleh software/aplikasi dengan melakukan pembuatan program; (5) testing dan evaluasi sistem - pengujian dilakukan terhadap aplikasi sistem dan model yang dikembangkan apakah sesuai dengan kebutuhan user (Shneiderman, 1998).

\section{Desain Model}

Langkah pertama adalah melakukan studi literatur, pencarian data dan informasi baik dari media cetak maupun internet, untuk mendapatkan informasi terkini mengenai perkembangan metode dan model perancangan penelitian, dan juga untuk mengetahui dan mempelajari metode yang telah ada dan sedang digunakan. Selanjutnya, pencarian data/informasi faktual dilakukan pada beberapa institusi/departemen yang tersebar di daerah sasaran penelitian yang dianggap dapat mewakili. Hasil pengumpulan data secara empiris digunakan sebagai bahan untuk menyusun model hubungan antar file yang dibutuhkan (Connolly dan Begg, 2002) serta pemahamannya dalam hal keuntungan pemakaian Algoritma Bezier dan B-Spline ( Edward, 1990).

\section{Implementasi Model}

Model yang didapat dari survei kemudian diimplementasikan dalam suatu software yang dapat digunakan oleh institusi atau departemen di daerah yang disurvei. Selain software tersebut, disusun juga suatu panduan bagi pengguna untuk lebih memudahkan penggunaan software. Dari pemakaian software tersebut, dilakukan evaluasi dari pengimplementasian model untuk penyempurnaan lebih 
lanjut. Evaluasi terhadap implementasi tersebut dilakukan dengan menggunakan kuesioner untuk mendapatkan umpan balik.

\section{Verifikasi Model}

Verifikasi model dilakukan terhadap persamaan awal yang digunakan dan hasil survei terhadap pemakaian software yang dikembangkan. Untuk pembuatan model perancangan penelitian tersebut, dilakukan analisis yang berpengaruh terhadap sistem software yang dirancang.

\section{Road Map/RIP UBINUS}

Peminatan Soft-Computing Jurusan Teknik Informatika Binus University mengarahkan lulusannya sebagai pengembang aplikasi system informasi khususnya di bidang Graphics and Computing. Tidak menutup kemungkinan untuk penelitian di domain Soft-Computing lainnya. Sistem grafik ini merupakan suatu masalah dalam perindustrian untuk pembuatan objek berupa angka, huruf, gambar-gambar serta objek yang diiginkan pemakai. Penelitian ini pernah dilakukan mahasiswa sebagai proyek dengan bimbingan Ketua Proyek waktu itu Djunaidy Santoso Dipl.Ing.;M.Kom.

Dalam bidang ini perlu diperdalam/dikembangkan karena merupakan titik yang banyak diminati oleh industri yang semakin memikirkan bisnis, karena produk barang dengan menggunakan algoritma tersebut sangat menguntungkan industri. Dalam membuat rancangan ini perlu metoda perancangan sistem, juga diperlukan system database yang handal dan metoda perancangan layar yang nyaman untuk pengguna(user), sehingga keluaran yang didapat lebih cepat, akurat dan sesuai kebutuhan, karena software yang dibuat mempergunakan menu-menu yang mudah dicerna. Sehingga dapat membantu pengambilan keputusan dari para pengguna. Metoda perancangan ini juga berdasarkan system development life cycle (Pressman, Roger S.(2001), Software Engineering: A Practioner' s Approach, 5th Ed.,MC Graw - Hill, New York),sehingga memudahkan para perancang untuk mengembangkan atau memelihara sistem tersebut dengan cepat dan baik. Penelitian di bidang sistem ini diarahkan sejalan dengan road map penelitian di Teknik Informatika Bina nusantara University (Gambar 1).

\section{HASIL DAN PEMBAHASAN}

\section{Uji Coba dan Hasil}

Hasil didapat bila program diatas dijalankan dengan mengcopy program $\mathrm{C}++$ dengan menginstalasi opengl (Inti grafik) kedalam komputer, yang ingin digunakan untuk menguji kebenaran Algoritma Bezier dan B-Spline tersebut melalui display monitor bukan printer, karena tidak akan terlihat kemulusan dari Kurva tersebut (CD ROM terlampir bila diinginkan akan diberikan dan program yang tidak masuk kedalam Artikel/Paper ini). Berikut ini adalah hasilnya (Tabel 1). 


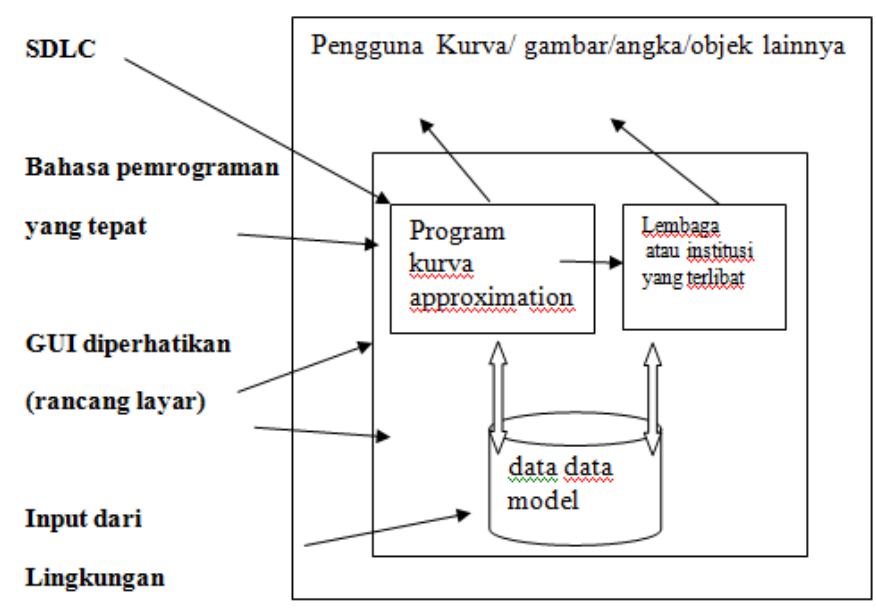

Gambar 1 Kerangka pemikiran penelitian

Tabel 1 Hasil uji coba software

\begin{tabular}{cll}
\hline Uji Coba & Berhasil & \multicolumn{1}{c}{ Masalah } \\
\hline \multirow{2}{*}{ Pertama } & sebagian & Di menu menu \\
\cline { 2 - 3 } & sebagian & Di saving dan editing data \\
\cline { 2 - 3 } & sebagian & Di drawing data \\
\hline \multirow{2}{*}{ Kedua } & OK & Dinamis menu \\
\cline { 2 - 3 } & OK & Hapus dan tambah data model \\
\cline { 2 - 3 } & OK & Untuk buat dan gambar model \\
\hline
\end{tabular}

\section{PENUTUP}

Dari hasil uji coba software ini, diambil kesimpulan bahwa menu program sudah mencukupi, data model sudah di gambar sesuai dengan Algoritma yang ada dan gambaran tersebut menjadi lebih baik/mulus sesuai dengan keinginan pengguna. Dari hasil coba yang pertama, sebagian masalah menu(GUI), editing dan data serta drawing data teratasi. Dari hasil coba yang kedua, keseluruhan masalah Dinamis menu, Hapus dan tambah data model, Untuk buat dan gambar model yang bagus dan mulus sesuai keinginan perancang atau pengguna yang sesuai dengan tujuan yaitu untuk merancang kurva/gambar/citra bagi industri otomotif (gambar mesin), kapal terbang/laut, desain rumah dan lain lain. Saran untuk penelitian selanjutnya adalah perlu pemikiran dan evaluasi hardware terutama monitor display yang resolusinya tinggi serta CPU yang memadai bila datanya besar sekali untuk menggambar model tersebut dan tambahkan perbandingan dengan Algoritma kurva lainnya. Tampilan menu bisa dalam keadaan statis dan baik.

\section{DAFTAR PUSTAKA}

Connolly, Thomas dan Begg, Carolyn. (2002). Database Systems (3rd edition). Boston: Addison Wesley Longman.

Edward, A. (1990). Computer Graphics 1. Boston: Addison-Wesley. 
Pressman, Roger S. (2001). Software Engineering: A Practioner's Approach (5th ed.). New York: MC Graw - Hill.

Rogers, David F. dan Adams, J.A. (1998). Mathematical Elements for Computer Graphics. New York: McGraw-Hill.

Shneiderman, Ben (1998). Designing the User Interface: Strategies for Effective Human-Computer Interaction (3rd edition). Boston: Addison-Wesley. 